\title{
ICTOРІЯ УКРАЇНИ
}

DOI https://doi.org/10.32782/2305-9389/2020.23.05

УДК 94(477)“1990/1991”

\author{
Аллеров Владислав, \\ військовослужбовечь \\ Національної гвардї Украӥни
}

\section{ПРОТЕСТНІ АКЦІЇ ГРОМАДСЬКО-ПОЛТТИЧНИХ ОРГАНІЗАЦІЙ, СПРЯМОВАНІ НА ВИРІШЕННЯ ПРОБЛЕМНИХ ПИТАНЬ ВІЙСЬКОВО-ПРИЗОВНИХ КАМПАНІЙ ДО ЗБРОЙНИХ СИЛ СРСР (1990-1991)}

У статті ретроспективно проаналізовано діяльність опозиційних до Комуністичної партї України (КПУ) громадсько-політичних організачій, які гостро критикували керівниитво СРСР за небажання реформувати Збройні сили СРСР. Інтервенція Радянського Союзу (СРСР) до Афганістану (1979-1989 р.), поглиблення процесів гласності, демократизачіï на зламі 1980-х - 1990-х років (створення «неформальних» товариств, проведення виборів на альтернативній основі тощз), швидка політизація молодіжного середовища привели до політизаціі військово-призовних кампаній в Украӥнській РСР, актуалізували питання проходження громадянами УРСР строкової військової служби на територї своєї республіки. Вибори до Верховної Ради Української РСР (1990 р.) та формування політичної опозиції в парламенті (Народна Рада) стали тими каталізаторами, щьо перетворили проблему військового будівниитва на одну з першочергових для національно-демократичних сил.

Зазначено, щзо завдяки неформальним товариствам, політичним партіям у 1990-1991 рр. в Украӥнській РСР значного поширення набув антиармійський рух, основні вектори якого спрямовувалися на бойкот, зрив військовопризовних кампаній до Збройних сил СРСР, утвердження в суспільній свідомості ідеї створення національних Збройних сил. Представники опозиційних політичних сил мали власне бачення на вирішення проблем призовників у період військових призовних кампаній 1990-1991 рр. Націонал-демократи наголошували на необхідності: проходження військової служби мешканцями Украӥни тільки на території республіки; припинення проходження військової служби на території України мешканиями інших республік; відкликання мешканців України, які проходять військову службу за межами Украӥни, на територію республіки; творення українських Збройних сил; надання можливості для проходження альтернативної військової служби на території Украӥни; поступового переходу на професійні Збройні сили тощуо.

Ключові слова: Збройні сили СРСР, Украӥнська РСР, громадсько-політичні організації, протестні акції, військова служба, Компартія Украӥни.

\footnotetext{
Allerov Vladyslav. Protest actions of social and political organizations are aimed at solving problems of military call campaigns to the Armed Forces of the USSR (1990-1991)

The article retrospectively analyzes the activities of public and political organizations in opposition to the Communist Party of Ukraine (CPU), which sharply criticized the USSR leadership for its unwillingness to reform the USSR Armed Forces. Soviet Union (USSR) intervention in Afghanistan (1979-1989), deepening publicity processes, democratization at the turn of the 1980s and 1990s (creation of «informal» societies, holding elections on an alternative basis, etc.), rapid politicization of the youth environment led to the politicization of military conscription campaigns in the Ukrainian SSR, brought up the issue of citizens of the USSR conscription on the territory of their republic. Elections to the Verkhovna Rada of the Ukrainian SSR (1990) and the formation of a political opposition in parliament (the Peoples Rada) became the catalysts that turned the problem of military construction into one of the top priorities for the national democratic forces.
}

It is noted that due to informal societies, political parties in 1990-1991 in the Ukrainian SSR became widespread anti-army movement, the main vectors of which were aimed at boycott, disruption of conscription campaigns in the USSR Armed Forces, the establishment in the public consciousness is the creation of national Armed Forces. Representatives of opposition political forces had their own vision for solving the problems of conscripts during the military conscription campaigns of 1990-1991. The National Democrats stressed the need to: military service by residents of Ukraine only in the republic; termination of military service on the territory of Ukraine by residents of other republics; recall of residents of Ukraine who serve in the military outside Ukraine to the territory of the republic; creation of the Ukrainian Armed Forces; providing opportunities for alternative military service on the territory of Ukraine; gradual transition to a professional Armed Forces, etc.

Key words: Armed Forces of the USSR, Ukrainian SSR, public and political organizations, protests, military service, Communist Party of Ukraine. 
В останні роки існування СРСР (1990-1991 рр.) в Українській РСР зросла кількість акцій опозиційних до Комуністичної партії України (КПУ) політичних сил, які були спрямовані на вирішення проблемних питань військово-призовних кампаній до Збройних сил СРСР. Підгрунтя акцій непокори було закладено у 1987 р. - в УРСР створено перші не підконтрольні партійно-державним органам влади т. зв. «неформальні» громадські організації, за сприяння яких у 1990-1991рр. організовано несанкціоновані владою мітинги та вуличні маніфестації. Громадські ініціативи спрямовувалися на врегулювання питань проходження громадянами Української РСР військової служби на території республіки, створення національних Збройних сил, республіканського Військового комісаріату тощо.

Досліджувані у статті проблеми належним чином не відображені в українській та зарубіжній історіографії, яку умовно поділяємо на два тематичні блоки - наукові праці, які в загальних рисах відображають процес зародження та розбудови громадянського суспільства в Українській РСР (В. Баран [1], В. Верстюк [2], С. Віднянський [3], О. Гарань [4], Г. Гончарук [5], О. Дергачов [6], В. Литвин [7], О. Мотиль [8], Ю. Шведа [9] та ін.) та наукові студії, які присвячені Збройним силам СРСР в останні роки перебудови (В. Баранівський [10], В. Бринцев [11], О. Бодрук [12], О. Кузьмук [13], В. Мартиросян [14], А. Папікян [15], А. Русначенко [16], Г. Темко [17], М. Томчук [18] та ін.). На жаль, військово-призовним кампаніям до Збройних сил СРСР в окреслених наукових працях не приділено належної уваги.

Основна мета статті - охарактеризувати громадські ініціативи, спрямовані на вирішення численних проблемних питань військово-призовних кампаній 1990-1991 рр., які проходили в умовах формування багатопартійної системи.

У 1990 р. в Українській РСР набирає сили потужний антиармійський рух, основним епіцентром якого стають західноукраїнські області. «Радикальні зміни у суспільстві, що дістали назву перебудови, можливі лише за умов найширшої гласності, якої так боїться партійно-бюрократичний клас, звиклий паразитувати на тілі мовчазного народу. Народ вийшов на майдани, щоб сказати своє слово», - наголошували опозиційні політики [19, с. 2]. На не санкціонованих владою мітингах, акціях непокори уперше в республіці звучать вимоги до влади військово-політичного характеру.

Перші потужні мітинги з яскравою військовою домінантою прокотилися Українською РСР 23 лютого 1990 р. (день Радянської Армії) [20, с. 2]. Неформали зазначали: «Українська нація - одна із наймогутніших націй у світі! Українська нація мала не тільки свою державу, але й мала велику військову славу. Ми виступаємо за те, щоб відродити ії військову славу - славу самостійної України! Ми не забуваємо, що українське військо ніколи не було окупантом. Наші воїни були воїнами-мстителями, воїнами-захисниками своєї рідної землі» [20, с. 2].

Через місяць, 31 березня 1990 р. у Львові відбувся несанкціонований мітинг, під час якого народний депутат УРСР В. Чорновіл зазначив, що «ми всі окуповані більшовиками і повинні вимагати незалежності <...> Якщо потрібно, львів'яни почнуть громадську акцію непокори». Народний депутат УРСР, співголова місцевого «Меморіалу» М. Косів не виключав можливість створення загонів добровольців для направлення їх до Литви [21, с. 3].

1 квітня 1990 р. у Києві відбувся несанкціонований мітинг, де керівник київського відділу Української Гельсінської Спілки (УГС), народний депутат Української РСР О. Шевченко закликав присутніх «не служити в окупаційній армії» i «не складати присягу» [22, с. 3]. У цей же період під час пікетування Львівського облвоєнкомату один із протестувальників, Т. Родцевич, заявив облвоєнконкому, що під час весняного призову «він недорахується як мінімум однієї третини призовників. «Заява була явно провокаційною і направлена на те, щоб не наставити призовників на шлях істинний, а підштовхнути їх до кримінального злочину», - писали компартійні 3МI, коментуючи перебіг мітингу [22, с. 3]. Додамо, що як реакція на нові виклики (збільшення кількості «уклоністів») при Генеральному Штабі Збройних сил СРСР була створена спеціальна комісія з виявлення осіб, які ухиляються від служби, і повернення їх до частин [22, с. 3].

10 червня 1990 р. відбувся черговий мітинг біля збірного пункту Львівського обласного військкомату, організований представниками національно-демократичних сил, Комітетом за створення національних Збройних сил. Коментуючи його проведення, газета «Слава родины» із безпідставним обуренням писала: «Ближче до вечора біля воріт < .. > з'явилися люди з синьо-жовтими прапорами. Почався мітинг. Про що на ньому йшла мова? Наприклад, зміст виступу І. Цимбала зводився до того, що сьогодні ті, хто йде до армії, автоматично перетворюється на душителів національних рухів, які розгорнулися в Україні, інших республіках. Спасти ситуацію може тільки створення національної армії, яка ніколи не буде стріляти по власному народу, а для цього необхідно парламентським шляхом ухвалити закон, який би дозволив українцям відбувати військову службу в межах республіки...» [23, с. 1]. 
Мітинг завершився прийняттям резолюції, в якій вказувалося, що Збройні сили СРСР - це вороги демократії. Прийнято рішення звернутися до Верховної Ради Української РСР із вимогою прийняти закон, який би дозволяв проходити військову службу українцям на території республіки, та почати кампанію громадянської непокори. Оцінюючи результати мітингу, комуністи зазначали: «Організатори мітингу потрудилися добре. I синьо-жовтих прапорів вистачало, і критики. Однак зірвати планову роботу обласного збірного пункту, привернути під свої прапори призовників їм не вдалося <..> Загалом проблеми призову молоді на службу до Збройних Сил далеко не однозначні...» [23, с. 1].

У відповідь на хвилю протестних антиармійських мітингів, 29 липня 1990 р. газета «Известия» опублікувала статтю заступника Генерального штабу Збройних сил СРСР Г. Кривошеєва, в якій він виклав власні міркування щодо можливості створення національних Збройних сил та повернення на територію республіки українських військових [24, с. 1]. Він зазначав: «Чого я негативно ставлюся до ідеї республіканських армій? Тому що вважаю: оборону країни не можна розтягувати по національних квартирах. Це просто несерйозно, якщо не сказати більше. Розташовуючи ракетні частини, ППО, флот, сухопутні війська, ми виходимо зі стратегічних та оперативних міркувань, а не з демографічних, чи в окремих випадках егоїстичних настроїв у тому чи тому регіоні» [24, с. 1$]$.

Значного суспільного резонансу набули серпневі події у Києві. Так, 23 серпня 1990 р. група військовослужбовців, які відбували строкову військову службу за межами України та самовільно повернулися на батьківщину, оголосила голодування [25, с. 1]. У відкритому листі до військового прокурора Київського гарнізону М. Стєпанова вони зазначали: «Ми солдати та сержанти, самочинно залишили свої військові частини з причин міжнаціональних, позастатутних відносин, «дідовщини», беззаконня з боку командування частин, приїхали шукати своїх законних прав, честі та гідності, гарантованих нам Конституцією СРСР та УРСР, на Україну. Але і на батьківщині ми зустріли бездушшя і нелюдське ставлення з боку < ..> командування Київського військового округу» [26, с. 2].

Військовослужбовці зазначали, що вони не можуть повернутися до своїх військових частин, як того вимагає військова прокуратура, оскільки «наперед знають, що будуть там репресовані і притягнуті до кримінальної відповідальності, а також не вірять, що командування військових частин забезпечить рівні і справедливі умови служби і захисту особистої гідності...» [26, с. 2]. Враховуючи ці обставини, військовослужбовці заявили, що вони: а) не залишать територію України, навіть якщо їм буде загрожувати фізична небезпека; б) у разі притягнення до кримінальної відповідальності будуть вимагати статусу політичних в'язнів; в) оголошують голодування до того часу, доки не буде прийнято рішення про можливість відбування військової служби на території України [26, с. 2].

Станом на 1 вересня 1990 р. на гауптвахті Київського військового гарнізону перебувало бл. 50 «дезертирів» (військових, які самовільно покинули військові частини поза межами Української РСР), які чекали розгляду їхніх адміністративних справ військовою прокуратурою. «Наші сини в небезпеці, писали незалежні періодичні видання. - Вимагаймо від уряду України негайно розпочати переговори з урядами інших республік та Міністерством оборони СРСР, згідно з Декларацією про державний суверенітет України, про якнайшвидше повернення військовослужбовців з України до дому, а мешканців інших республік вивести з військових частин України» [27, с. 6].

Опозиційна до КПУ преса публікувала на своїх шпальтах заяви батьків, діти яких самовільно покинули військові частини за межами Української РСР. «Прошу забезпечити відбування служби в межах республіки (зрозуміло, не в Чорнобилі) та вжити дієвих заходів для такої реформи армії, яка виключала б дідівщину, а доти - дайте нашим дітям спокій. Ми не надавали Вам повноважень калічити наших дітей. Не вмієте творити цивілізованого високопрофесійного війська - звільніть місце для здібних і відповідальних», - писав батько О. Фіценка Президенту СРСР М. Горбачову [28, с. 8].

Принагідно зазначимо, що якщо 23 серпня 1990 р. голодування оголосили 16 військовослужбовців ((Майоров, Почкін, Адаменко, Сидоренко, Гастомельський, Лєсніков, Лєсков, Дука, Тарашевський, Ісанський, Іщенко та ін.), 25 серпня голодуючих залишилося 6 (Майоров, Почкін, Гастомельський, Лєсков, Дука, Тарашевський), а 28 серпня голодували тільки двоє (Майоров, Почкін). Інші військовослужбовці були змушені припинити голодування через погіршення здоров'я. 27 серпня 1990 р. на гарнізонній гауптвахті знаходилися 22 військовослужбовці, з яких 12 до 1 вересня були відправлені військовою прокуратурою до своїх військових частин $[28$, с. 8].

Голодування військовослужбовців отримало широкий суспільно-політичний відгомін. Так, у Зверненні Міжпартійної Асамблеї зазначено: «Імперська влада, Міністерство оборони СРСР та його комісаріати в Україні глумляться над Декларацією [про державний суверенітет України - aвm.] як над такою, що не має жодної юридичної сили <...> Наближається час рекрутського набору і тисячі наших дітей 
поповнять окупаційні війська у республіках Прибалтики, стануть з автоматами на вулицях і площах закавказьких міст» [29, с. 1$]$.

30 серпня 1990 р. біля будівлі Київського військового округу з ініціативи Комітету солдатських матерів України відбулося пікетування з вимогою негайного повернення військовослужбовців-українців на територію України для продовження військової служби. До протестуючих вийшов генерал-майор О. Діхтяренко, який зазначив: «Совєтська армія підкоряється закону СРСР «О прохождении воинской служби». Ніким він не скасований, і тому хлопців буде відправлено до їх військових частин, бо за цим законом вони є дезертирами і їхні справи на місці будуть передані до військових прокуратур» [30, с. 1].

1 вересня 1990 р. на площі Жовтневої революції в Києві відбувся мітинг, організований Комітетом солдатських матерів України, Київським громадянським та страйковими комітетами, Українською міжпартійною асамблеєю. Участь у заході взяли понад 10 тис осіб. На думку журналістів неформального часопису «Вісті», основний акцент «було зроблено на тому, що Верховна Рада УССР, прийнявши Декларацію про державний суверенітет фактично спричинив масову втечу з Радянської Армії молоді України, яка бажає служити в Україні і для України». Зазначено, що «покинувши свої частини, юнаки стали об'єктом полювань військових жандармів, а взяти їх під свій захист депутати від Народної Ради не спромоглися» [31, с. 1].

У підсумковій резолюції поставлено вимоги до центральної влади Української РСР: «Негайно припинити участь представників УРСР у підготовці нового союзного договору; негайно звільнити всіх захоплених людоловами юнаків, котрі самочинно залишили військові частини імперської армії і повернулися в Україну; передати їх батькам до вирішення питання їх розміщення по військових частинах в Україні; вирішити ці питання лише за участю представників комітету матерів; при обласних, міських радах створити пункти збору втікачів з імперського війська, взявши їх під захист рад» [31, с. 1]. Із гаслами «Руки геть від хлопців, котрі покинули військові частини імперської армії!» демонстрація вирушила до міської комендатури, де мітинг було продовжено [31, с. 1].

Напередодні початку осінньої призовної кампанії 1990 р., 15 вересня 1990 р. у Києві відбулася нарада представників страйкомів та робітничих комітетів України (були присутні представники комітетів Донецької, Полтавської, Запорізької, Чернігівської, Київської, Львівської, Тернопільської, Закарпатської і Ровенської областей) [32, с. 1]. За підсумками її роботи ухвалено Заяву, в якій прийнято рішення взяти участь у Всеукраїнському попереджувальному страйку 1 жовтня з таким пакетом вимог до Верховної Ради Української РСР: відмова від нав'язування Україні оновленого Союзного Договору, оновленої форми кабали; не допустити проходження військової служби осіннім та подальшими призовами за межами республіки, забезпечити реальне виконання постанови Верховної Ради УРСР від 30 липня 1990 року про повернення на Україну всіх, хто проходить військову службу за іії межами сьогодні; задовольнити економічні та політичні вимоги шахтарів Донбасу, деполітизувати державні установи, армію, КДБ, МВС; націоналізувати майно КПРС на території України, нажите за рахунок зрощення партійних та державних управлінських структур; визнати комуністичну ідеологію і практику злочином проти людства та ін. [33].

«Верховна Рада прийняла свою постанову від 30 липня, а Президія не забезпечила реального ії виконання. Міністром оборони Союзу ця постанова зараз не виконується. Щодо наших вимог, то всі вони фактично є в дусі Декларації, але питання зараз стоїть так: ця Декларація залишиться Декларацією про суверенітет, чи вона стане документом і законом?» - зауважував координатор Київського страйкового комітету [33]. Принагідно зазначимо, що станом на кінець вересня 1990 р. у Вірменії, Азербайджані, включаючи Нагірно-Карабахську автономну область, перебував 1121 військовослужбовець особового складу внутрішніх військ. Із них 35\% - призовники з Української РСР (близько 400 осіб). Передбачалося до 5 жовтня вивести до республіки батальйон (200 осіб), а до 5 грудня - завершити поетапне виведення усіх військ на місце постійної дислокації [34].

Відсутність прогресу у питанні суверенізації Української РСР радикалізувала суспільні настрої, що стало очевидним восени 1990 р.: 2 жовтня розпочалася студентська акція непокори («Революція на граніті») [35, с. 10]. Остання подія пришвидшила процес законодавчого регулювання проходження строкової військової служби на території України, оскільки це була одна 3 найважливіших вимог протестуючих. Згадуючи про особливості формування політичних вимог, О. Доній зазначав: «Там було кілька вимог, спочатку дві, потім - три: перевибори Верховної Ради та націоналізації майна Компартії України і ВЛКСМ, потім додалося - непідписання Союзного договору <...> А львів'яни приїхали вже з іншими проханнями: відставка прем'єр-міністра Масола та служба українських вояків лише на території України» [36].

Проте практика показувала, що Міністерство оборони СРСР не планувало йти на поступки Верховній Раді Української РСР. 13 листопада 1990 р. Рада Міністрів УРСР отримала від Міністерства 
оборони СРСР наступні пропозиції - до військ і сил стратегічної оборони і флоту запропоновано призвати відправкою за межі республіки 39,1\% молоді, яка призивалася восени 1990 р. [37] «Це значить, що порівняно з раніше розробленим планом кількість призовників до такого роду військ із нашої республіки зменшується приблизно на 10 процентів», - зазначали в Уряді УРСР. У Раді Міністрів УРСР пропонували «у такому випадку осінній призов 1990 року розглядати $<\ldots>$ як перехідний на шляху до повного виконання рішень Верховної Ради республіки». Отже, Уряд республіки пропонував із «цим погодитись, якщо згадана квота для військ стратегічної оборони і флоту буде підтримана Верховною Радою республіки [37].

Додамо, що на початку листопада 1990 р. безпрецедентні за своїми масштабами протесті акції відбулися в Запоріжжі - кращий полк ППО Української РСР висловив недовіру командуванню і Міністру оборони, оскільки було підписано наказ про передислокацію цього полку до Казахстану. Через три тижні було досягнуто компромісне рішення про те, що техніка перебазується, а офіцерам, прапорщикам і солдатам буде надана змога за станом здоров'я або за вислугою років піти на пенсію. Однак після того як техніку було відправлено за місцем призначення, оприлюднено новий наказ, який перекреслив раніше прийняту домовленість (наказано прибути до місця дислокації). Подібні дії Міністерства оборони СРСР привели до початку голодування біля будівлі облвиконкому дружин офіцерів, у Запоріжжі відбувся мітинг [37].

Загроза введення радянських військ до країн Балтії, підготовка всесоюзного та «галицького референдумів» 17 березня 1991 р., критичні відгуки обласних рад на хвилю «мітингової демократії», зневіра у можливості вирішення проблем призовників - ці та інші фактори вплинули на зменшення інтенсивності «мітингової демократії», зокрема тих акцій національно-демократичних сил, які спеціально приурочувалися проблемі військово-призовних кампаній. Зауважимо, що 23 червня 1991 р. на мітингу в Києві прийнято «Ухвалу», яка засуджувала підписання нового союзного договору. У документі зазначено: «336 років Україна була колонією Російської і Радянської імперій. За цей час вона доведена до економічної, екологічної і духовної руїни. Найновіший новоогарьовський проєкт договору за своїм змістом не є Договором про Союз Суверенних Держав. Він переслідує єдину мету - збереження неподільної радянської імперії, є лицемірно, недбало закамуфльованою обіцянкою суверенітету республікам, запозиченої зі сталінсько-брежневської Конституції. Він не лише передбачає збереження СРСР як тоталітарної наддержави, захищеної успадкованими від попередньої автократичної системи армією, КДБ, МВС і КПРС, гіпертрофованим військово-промисловим комплексом, а також Конституцією, президентською владою, Кабінетом Міністрів, судами та прокуратурою СРСР. На утримання цієї величезної тоталітарної машини будуть і надалі витрачатися колосальні кошти, що приречує народи «оновленого» Союзу на подальше злиденне животіння» [38].

Отже, у 1990-1991 рр. після утворення «неформальних» громадсько-політичних організацій, а згодом політичних партій в Українській РСР прокотилася хвиля мітингів, які опосередковано або ж безпосередньо присвячувалися проблемним питанням військово-політичного характеру. Відновлення незалежності Української держави поставило остаточну крапку в боротьбі опозиційних до КПУ політичних сил за створення національних Збройних сил, відбування строкової військової служби громадянами України на території республіки.

\section{Література:}

1. Баран В. Україна: новітня історія (1945-1991 рр.). Львів : Інститут українознавства ім. І. Крип’якевича НАН України, $2003.670 \mathrm{c.}$.

2. Карабанов М. Від всевладдя до краху (КПРС-КПУ в 1985-1991рр.). Київ : Освіта, 1993.75 с.

3. Верстюк. В. Україна: утвердження незалежної держави. Київ, 2001. 193 с.

4. Віднянський С., Мартинов А. Державотворчий процес в Україні 1991-2006. Київ : НВП «Видавництво «Наукова думка» НАН України», 2007. 269 с.

5. Гарань О.В. Україна багатопартійна: програмні документи нових партій. Київ, 1991. 191с.

6. Гончарук Г.І. Народний Рух України. Історія. Одеса : Астропринт, 1997. 380 с.

7. Українська державність у XX столітті. Історико-політологічний аналіз / кер. авт. кол. О. Дергачов. Київ, 1996. 716 с.

8. Литвин В. Украина; политика, политики, власть. На фоне политического портрета Л. Кравчука. Киев : Издательский дом «Альтернативы», 1997. 335 с.

9. Мотиль О. Підсумки імперій: занепад, розпад і відродження. Київ : Критика, 2009. 367 с.

10. Шведа Ю. Багатопартійність і проблеми становлення громадянського суспільства в Україні. Вісник Львівського Університету. 1993. Вип. 31. С. 48-53.

11. Баранівський В. Демократизація Збройних Сил України. Київ : Центр практ. філос., 2001. 111 с.

12. Збройні Сили незалежної України. Перші 10 років (1991-2001) / За ред. В. Бринцева. Київ : НАОУ, 2006. 378 с.

13. Бодрук О. Структури воєнної безпеки: національний та міжнародний аспекти : монографія. Київ : НІПМБ, 2001. 300 с. 
14. Військове будівництво в Україні у ХХ столітті: історичний нарис, портрети / За заг. ред. О. Кузьмука. Київ : Видавничий Дім «Ін Юре», 2001. 448 с.

15. Мартиросян В. Спілка Офіцерів України. Шануймося, панове офіиеери. Київ : Варта, 2001. С. $183-197$.

16. Папікян А. Збройні сили України двадцятого століття. Львів : КП «Видавництво Кобзар», 1999. 308 с.

17. Русначенко А. На шляху до національної армії. Утворення Спілки офіцерів України. Шануймося, панове офіцери. Київ : Варта, 2001. С. 7-44.

18. Темко Г. Будівництво Збройних Сил України: проблеми і перспективи. Украӥнський історичний журнал. 1996. Вип. 4. С. 13-23.

19. Томчук М. Розбудова армії і національна безпека. Політика $і$ час. 1993. Вип. 4. С. 40.

20. Мітинги та демонстрації. Голос відродження. 1989. № 1. С. 2.

21. В чьих интересах антиармейские призывы? Слава родины. 1990. 28 февраля. С. 2.

22. Кому выгодна конфронтация? Сообщение пресс-центра ЦК Компартии Украины. Слава родиныл. 1990. 10 апреля. С. 3.

23. Родители, будьте благоразумны! Слава родины. 1990. 24 апреля. С. 3.

24. Партин Е. К чему зовут подстрекатели? Еще раз о проблемах, связанных с призывом в армию. Слава родины. 1990. 13 июня. С. 1.

25. Партин Е. К чему зовут подстрекатели? Еще раз о проблемах, связанных с призывом в армию. Слава родины. 1990. 13 июня. С. 1.

26. Будет ли на Украине своя армия? Известия. 1990. 29 июля. С. 1.

27. Голодування вояків, які приїхали в Україну з інших регіонів Союзу Радянських Соціалістичних Республік, та не знайшли підтримки у військовій прокуратурі. Видноколо. 1990. № 2. С. 1.

28. Відкритий лист до військового прокурора Київського гарнізону. Видноколо. 1990. № 2. С. 2.

29. Чернишов С. Ні службі в окупаційній армії. Незалежність. 1990. № 6. С. 6.

30. Заява. Голос відродження. 1990. № 6. С. 8.

31. Звернення Виконкому Міжпартійної асамблеї. Вicmi. 1990. № 2. С. 1.

32. Пікет. Bicmi. 1990. № 2. C. 1.

33. Мітинг. Вicmi. 1990. № 2. С. 1.

34. Заява наради представників страйкових, робітничих та профспілкових комітетів України. Голос. Незалежний інформаиійний бюлетень. 1990. № 16. С. 1.

35. Стенограма засідання Верховної Ради Української РСР. Засідання 2 (1 жовтня 1990 p.). URL: https://www.rada.gov.ua/ meeting/stenogr/show/4437.html

36. Стенограма засідання Верховної Ради Української РСР. Засідання 6 (3 жовтня 1990 p.). URL: https://www.rada.gov.ua/ meeting/stenogr/show/4441.html

37. Студентська революція на граніті: Альбом / [авт. та упор. О. Доній]. Київ : Смолоскип, 1995. С. 10.

38. Революція на граніті: нас можна назвати циніками, які готові загинути за ідею. URL: https://www.istpravda.com.ua/ articles/2015/10/2/148579/

39. Стенограма засідання Верховної Ради Української РСР. Засідання 79 (27 червня 1991 p.). URL: https://www.rada.gov.ua/ meeting/stenogr/show/4582.html 